\title{
The effect of dietary L-ascorbic acid megadoses on the morphology of the lens in rats
}

\author{
T. Niemiec ${ }^{1,3}$, T. Ostaszewska ${ }^{2}$, E. Sawosz ${ }^{1}$ and M. Szmidt ${ }^{1}$ \\ Warsaw Agricultural University, \\ ${ }^{1}$ Department of Animal Nutrition and Feed Science, \\ ${ }^{2}$ Division of Ichthyobiology and Fisheries \\ Ciszewskiego 8, 02-786 Warszawa, Poland
}

\begin{abstract}
The aim of the present study was to evaluate the effects of diets containing L-ascorbic acid on the morphology of the eye lens in rats. The experiment was done on 40 Wistar rats. The animals were divided into 4 groups fed diets containing: I- 0.0 ; II- 0.3 ; III- 0.6 , or IV- $0.9 \%$ of L-ascorbic acid. Vitamin $C$ megadoses ( 0.6 and $0.9 \%$ ) caused an increase in lens capsule thickness and changes in its structure (an increase in the neutral glycoprotein content) and activity of the epithelial cells under the capsule.
\end{abstract}

KEY WORDS: rats, L-ascorbic acid, lens, pathomorphology

\section{INTRODUCTION}

Ascorbic acid determines the optimal structure of collagen via synthesis of hydroxyproline. Furthermore, vitamin $\mathrm{C}$ is an antioxidant of the body's water phase and is an important scavenger of reactive oxygen species (ROS), which can be generated as a result of UV irradiation. The eye lens consists of collagen containing high amounts of hydroxyproline. The lens is permanently exposed to solar radiation, and ascorbic acid probably protects it from damage by ROS. During growth and development, the ascorbic acid requirement may exceed the body's ability to synthesize it. Nonetheless, pro-oxidative effects of vitamin C have also been observed in in vitro and in vivo studies (Podmore et al., 1998; Ostaszewska et al., 2004).

The aim of this study was to determine the effect of megadoses of L-ascorbic acid added to rat diets on the morphological state of the eye lens.

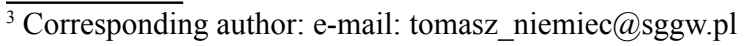




\section{MATERIAL AND METHODS}

Forty male Wistar rats, of an initial body weight $235.1 \mathrm{~g}$, were divided into 4 groups of 10 animals, and kept in individual cages for 41 days under standard conditions: temperature of $22^{\circ} \mathrm{C}$, air humidity $50-70 \%$, light/dark $12 / 12$. The rats received semipurified diets, containing, \%: maize starch I, 62.22; II, 61.92; III, 61.62; IV, 61.32, casein, 14.0; sucrose, 10.0; cellulose, 5.0; rapeseed oil, 5.0; mineral mix, 3.5; vitamin mix, 1.0; L-cystine, 0.18 , and chloride choline, 0.1 . The diets were supplemented with ascorbic acid (in \% of the mixtures): I, 0.0; II, 0.3; III, 0.6; and IV, 0.9. Lascorbic acid, mineral and vitamin mixtures were obtained from ICN Biomedicals. At the end of the experiment, the rats were euthanasized by an overdose of ketamine and the eye samples were collected immediately. They were fixed in $10 \%$ neutral buffered formalin, embedded in paraffin, sectioned at $6 \mu \mathrm{m}$ and stained with periodic acid-Schiff (PAS). The cell measurements were done using a Nikon-Alphaphot2YS2 microscope connected to a digital Nikon 4300 camera and MicroScan (v. 1.5) and Lucia 4.21 computer image analysis systems. The detailed examination of the cells was performed under $400 \times$ magnification. Histological analyses were performed to visualize the effects of vitamin $\mathrm{C}$ dose on morphological changes, including the morphometric parameters of the lens: the width of the lens filaments, integrated optical density of the lens filaments, nucleus volume, integrated optical density of the nucleus. The obtained results were analysed by one-way analysis of variance ANOVA, using the Statgraphics 4.1 computer program.

\section{RESULTS AND DISCUSION}

The lens capsule was the thickest in the rats of group IV (Figure 1C). It was PAS-positive in the animals of groups III $(0.6 \%)$ and IV $(0.9 \%)$ which indicates the presence of neutral glycoproteins, in contrast with the control and group II $(0.3 \%)$ animals, in which the lens capsule contained acidic glycoproteins. Moreover, the lens epithelium of the rats of group IV $(0.9 \%)$ showed the highest number of nuclei (Figure 1C). The optic density of the lens cytoplasm was the highest in group II, and the lowest in group IV, in which the largest nuclei occurred (Table 1).

Table 1. Morphometric parameters of lenses of rats fed diets with varied ascorbic acid content

\begin{tabular}{lcccc}
\hline $\begin{array}{l}\text { Dietary } \\
\text { ascorbate, } \%\end{array}$ & $\begin{array}{c}\text { Lens fibre } \\
\text { width, } \mu\end{array}$ & $\begin{array}{c}\text { Lens fibre optical } \\
\text { density }\end{array}$ & $\begin{array}{c}\text { Nucleus } \\
\text { volume, } \mu^{3}\end{array}$ & $\begin{array}{c}\text { Nucleus optical } \\
\text { density }\end{array}$ \\
\hline 0.0 & 8.18 & $150.34^{\mathrm{a}}$ & $100.38^{\mathrm{a}}$ & $321.70^{\mathrm{a}}$ \\
0.3 & 7.32 & $260.47^{\mathrm{b}}$ & $81.96^{\mathrm{a}}$ & $298.27^{\mathrm{a}}$ \\
0.6 & 8.19 & $150.40^{\mathrm{a}}$ & $284.60^{\mathrm{b}}$ & $422.17^{\mathrm{b}}$ \\
0.9 & 8.33 & $61.46^{\mathrm{c}}$ & $394.44^{\mathrm{c}}$ & $405.94^{\mathrm{b}}$ \\
SEM & 0.34 & 16.81 & 20.87 & 28.11 \\
\hline
\end{tabular}

a,b,c $\mathrm{P}<0.05$ 

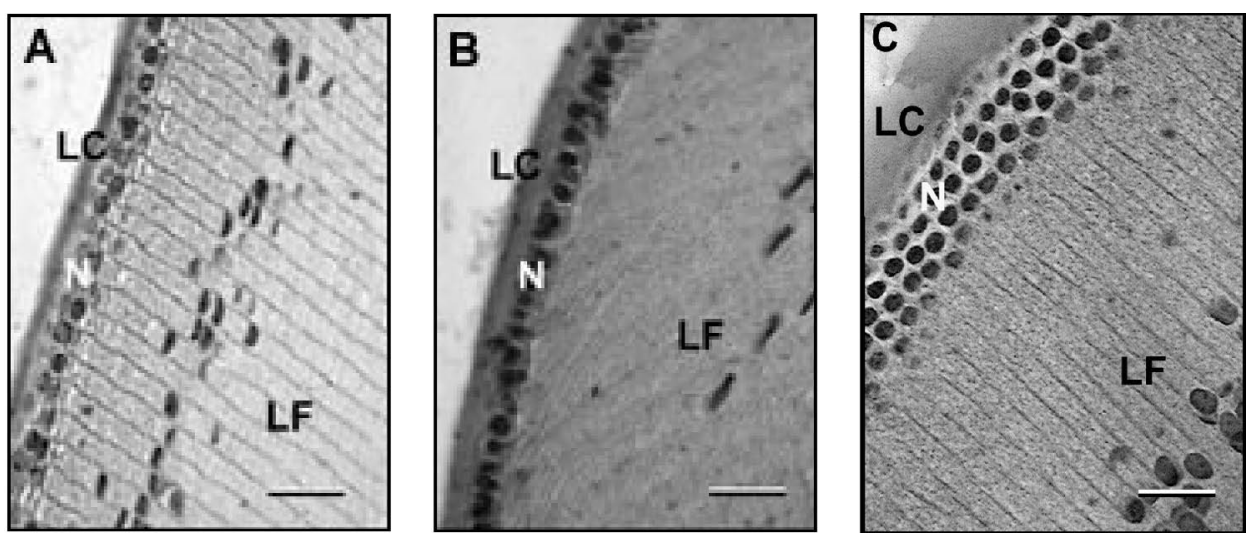

Figure 1. Cross-section of the lens of rats fed diets containing: A. $0 \%$, B. $0.6 \%$ C. $0.9 \%$ of vitamin C, LC - lens capsule, N - nucleus, LF - lens fibres. Scale bars $25 \mu \mathrm{m}$

Ultrastructurally, the support of the lens capsule is type IV collagen, which interacts with other glycoproteins and proteoglycans to form an extracellular matrix. Type IV collagen forms a resilient, three-dimensional molecular network (Krag and Andreassen, 2003). The laminated structures of the lens capsule can be damaged with age due to an increase in the ratio of non-collagenous to collagenous amino acids, especially hydroxyproline. The content of non-collagenous compounds determines the density of the lens capsule, and increases with age. The presence of neutral glycoproteins observed in the rats of groups III and IV probably points to changes in the lens capsule structure caused by vitamin C. The prooxidative effect of vitamin $\mathrm{C}$ was stated in vitro (Carr and Frei, 1999) and in vivo, based on evaluation of the DNA oxidation level (Niemiec and Sawosz, 2004) and morphological characteristics of hepatocytes (Ostaszewska et al., 2004). Oxidative degradation of hydroxyproline and glycoproteins might have resulted in adverse changes in chemical composition and an increase in lens capsule thickness (group IV). In both group IV and III, the nucleus density was elevated, and in group IV, also nucleus volume in the epithelial layer under the capsule was increased. This suggests increased metabolic activity of epithelial cells responsible for regeneration of possible damage to the lens capsule; their number suggests disturbances. Call et al. (2004) reported that the lens shows considerable ability for regeneration, thus it is possible that this process might be stimulated by vitamin $\mathrm{C}$ megadoses.

The lowest density of lens filaments occurred in the animals provided with $0.9 \%$ of vitamin C. The filaments are filled with a protein, crystallin, the composition of which changes over the lifetime. Supposedly, a decrease in cytoplasm density in the lens filaments might have resulted from degradation of cell membrane structures and an increase in membrane permeability due to reduction of the crystallin concentration caused by vitamin $\mathrm{C}$. This hypothesis requires further studies. 


\section{CONCLUSIONS}

Vitamin $\mathrm{C}$ megadoses ( 0.6 and $0.9 \%$ in diet) cause an increase in thickness and changes in the structure of the lens capsule: an increase in the amount of neutral glycoproteins, and increase in the activity of epithelial cells under the capsule.

\section{REFERENCES}

Banhegyi G., Braun L., Csala M., Puskas F., Mandl J., 1997. Ascorbate metabolism and its regulation in animals. Free Radical Biol. Med. 23, 793-803

Call M.K., Grogg M.W., Del Rio-Tsonis K., Tsonis P.A., 2004. Lens regeneration in mice: implications in cataracts. Exp. Eye Res. 78, 297-299

Carr A., Frei B., 1999. Does vitamin C act as a pro-oxidant under physiological conditions? FASEB J. 13, 1007-1024

Krag S., Andreassen T.T., 2003. Mechanical properties of the human lens capsule. Prog. Retin. Eye Res. 22, 749-767

Niemiec T., Sawosz E., 2004. Effect of addition of L-ascorbic acid megadoses to the diets on the antioxidative-oxidative state in rats. Proceedings of 8th International Conference of European Society of Veterinary and Comparative Nutrition. Budapest, pp. 258-259

Ostaszewska T., Sawosz E., Niemiec T., Bielecki W., 2004. Effect of the addition of L-ascorbic acid in megadoses to the diet on morphology of liver cells in rats. J. Anim. Feed Sci. 13, Suppl. 2, $47-50$

Podmore I.D., Griffiths H.R., Herbert K.E., Mistry N., Mistry P., Lunec J., 1998. Vitamin C exhibits pro-oxidant properties. Nature 392, 559 